Dr. Sibel Yoleri'

Assoc. Professor at the Department of Preschool Education Izmir Demokrasi University, Turkey
Original scientific paper

UDC: 37.018 .26

DOI: $10.5937 /$ IstrPed2101108Y

\title{
WHAT ARE THE EXPECTATIONS OF PARENTS FROM PRESCHOOL EDUCATION INSTITUTIONS? WHY DO THEY CHOOSE? WHAT ARE THEY WAITING FOR?
}

\begin{abstract}
The goal of this study was to investigate the expectations of the parents with a child enrolled at a preschool education institution from preschool education institutions. This research was designed as a survey study. The sample of this study consisted of 326 children, enrolled at preschool education institutions in the center of Usak province, and their parents. "Parents' Expectations from Preschool Institutions Questionnaire" developed by Simsek and Ivrendi (2014), and "Demographics Information Form" were used as data collection tools to determine the expectations of parents from preschool education institutions. It was concluded as a result of the study that the parents had a "low level" expectation related to the sub-scales of (teacher, education-family, school policy, informing) of the Parents' Expectations from Preschool Institutions Questionnaire. A significant difference in favor of males was found out in the informing sub-scale according to the t-test results carried out related to parents' expectations in line with the gender of children. The expectations of parents from preschool institutions showed a significant difference according to income status. It was found out that the expectations of families with low income level from preschool institutions were higher compared to the expectations of families with middle- and high-income levels regarding the sub-scales of teacher and education-family.
\end{abstract}

Keywords: Early childhood, Parent expectation, Preschool institution.

\section{Introduction}

As the contribution of women to economic development has been understood and more women have begun to take place in working life in last decade, regulations have been made in many countries related to the services providing support for care and development of children by enabling women to combine their family responsibility with their jobs (Penn, 2009; Council of the European Union, 2011; Bespinar \& Aybars, 2013). Studies show that the investments made to the early childhood education have high individual and social profits (Checchi, 2006; Lasser, \&Fite 2011; Meyers, Lucy\& Jordan, 2009; Rolnick \& Grunewald, 2003; Schulman \& Barnett, 2005). However, this mostly depends on the quality of early childhood education programs and institutions. When the quality is low, expected positive effects also become low.

'yoleriizmir@gmail.com 
The family is considered an institution with a permanent effect on an individual from his/her birth till his/her death, meeting his/her developmental and social needs, supporting his/her development and education. Bronfenbrenner's bio-ecological model, providing a conceptual framework to emphasize cooperation and mutual understanding between all stakeholders playing a role in the development and education of children, argues that personal development occurs in an interwoven, connected system set. The systems in bio-ecological model cover the following: micro-system (consists of a child's closest environment such as family-school; it has a direct effect in physical, social and psychological respects) (Berk, 2005); meso-systems (helps to connect two or more systems in which a child, parents and family are living in); exo-system (represents contexts experienced by a child indirectly yet affecting that child directly); macro systems (broader cultural beliefs, social values, political tendencies and social events); and chrono-systems (represents the historical context mediated by family dynamics). This model emphasizes the involvement of families in education and the importance of communication and cooperation between schools and families (Bronfenbrenner \& Morris, 2006).To clarify, parents are primary decision-makers in the early childhood period and are responsible for specifying the right early childhood education and care services in order to allow their children to take a proper education (Foot, Howe, Cheyne, Terras \& Rattray, 2000; Noble, 2007). In this regard, preschool education cannot be thought separate from families because permanence and quality of education provided at schools are closely related to the communication and cooperation between schools and families. In order to carry out this cooperation and communication properly and in accordance with the purpose, families should be involved in this process (Christenson \& Sheridan, 2001; Grolnick, Friendly \& Bellas, 2009) and the expectations of families and schools should be determined. Undoubtedly, families will show more involvement, desire, and interest as long as their expectations are met.

While determining the most appropriate preschool education institution for their children and themselves, families do not make a random choice, but they determine their priorities and expectations by considering certain criterion. Therefore, preschool education institution preference is not random but an intentional choice and the decision of going on such an institution seem changes to the extent their expectations and needs are met (Huston, Chang \& Gennetian, 2002; Yesil Dagli, 2012). The investigations have revealed that families may have expectations from preschool education institutions in different dimensions. It is indicated that parents consider factors such as cost, security and what they believe are best for their children while they are making a decision on a preschool education institution for their children. NAEYC (National Association for the Education of Young Children) has determined some standards to assess early childhood care and education programs. These standards help parents make a right choice in their search for proper kindergarten, nursery, and nursery class. These standards are as follows:

Relationships: A preschool education institution should develop positive relationships among all children and adults. Warm, sensitive, and mindful relationships help children feel safe; Curriculum: The curriculum should be children centered and should support their social, emotional, physical, linguistic, and cognitive development; Teaching: Children have different learning styles, needs, capacities, interests, and backgrounds. Teachers and staff help learning processes of all children by recognizing these differences and using proper teaching approaches for each child; Assessment of Child Progress: Assessment helps teachers to make a plan by responding to each child's strengths and needs; Development of Health and Safety: Nutrition and health of children should be supported, and measures should be taken to 
protect them from diseases and accidents. Children must be healthy and safe to learn and to grow; Staff Competencies and Support: Teachers should have necessary professional competence to support children's learning and development and to guide families; Families: Preschool education institutions should establish relationships with families of every child based on cooperation, mutual trust, and respect; Community Relationships: Preschool education institutions should use social resources in order to achieve program goals, should introduce families to the resources which may support healthy development and learning of children and should establish relationships with the social environments of children; Physical Environment: Preschool education institutions should have safe and proper physical environments in both indoor and outdoor areas. Such an environment facilitates learning of both children and adults and Leadership and Management: Preschool education institutions should be managed by effective policies and systems enabling all children, families, and staff to live high-quality experiences (NAEYC, 2008).

It is certain that all these standards do not apply to all families and their children because prior studies show that the views, thoughts and expectations of families are affected by needs, values, attitudes, age, gender, needs of families, income, economic and cultural factors (Ceglowski, \& Bacigalupa, 2002; Ceylan, 2019; da Silva \& Wise, 2006; Jacobson \& Engelbrecht, 2000; Liang, Fuller\& Singer, 2000;Noble, 2007; Simsek \& Ivrendi, 2014). Decision-making process may differ according to the characteristics of parents and children(Huston, Chang \& Gennetian, 2002;Peyton, Jacobs, O'Brien\& Roy, 2001). For this reason, while a family prefers an early childhood education institution, another family may choose another institution due to different reasons and preference factors may be highly personal (Glenn-Applegate, Pentimonti \& Justice, 2011).As parents are key stakeholders in enrolling their children in preschool education institutions, decision-making processes and causes should be understood better in the designation of programs to promote more equal access of children to highquality early childhood education services (Forry, Simkin, Wheeler \& Bock, 2013; Navarro-Cruz \& Luschei, 2020). For example, satisfied parents are in a tendency to become loyal and faithful to the schools in which their children are enrolled (Daphina \& Begi, 2020). In studies on satisfaction levels of parents, teaching quality, feedback quality parents receive and cooperation between school-family are among the subjects reported frequently (Fantuzzo, Perry \& Childs, 2006). In the research by Friedman, Bobrowski and Markow (2007), and Friedman, Bobrowski and Geraci (2006), basic factors building satisfaction of parents have been labelled as follows: efficiency of teachers, communication with parents and ensuring their involvement in school life, administrators, quality of the curriculum, technology, facilities, involvement, transportation and budget.

As mentioned above, various variables affect the satisfaction and expectations of parents from the schools where their children are enrolled. For this reason, to know parents' views and perceptions about the quality of preschool education, to what extent their expectations are met, and their level of satisfaction is of importance in informing policymakers and service providers. What is more, assessment of parent expectations related to early childhood services allow to understand the relationships developing between two main environments (family and school) of children. For this reason, this research had more than one purpose. The first one was to determine the expectations of parents whose children are enrolled in preschool education institutions. The final purpose of this study was to reveal whether some variables (gender of children, income level of families) had any effect on families' expectations from preschool education institutions. 


\section{Methods}

\section{Research Design}

This study was designed as a descriptive research and "survey model" was used in this investigation. Survey model is a research approach aiming to describe a past or existing situation as it was. The event, individual or object being researched is attempted to be described as it is within its own conditions (Karasar, 2012). The survey model was used in this investigation because it aimed to uncover the parents' expectations from preschool education institutions, whether there was a relationship between their expectations and the relationship between gender of children and socio-economic conditions of families, which are considered to have an effect on parents' expectations.

\section{Participants}

The sample group of this study consisted of 326 children of 5-6 years of age who were living and receiving preschool education in the province of Usak, Turkey. 176 (54\%) of participating children were girls, and 150 (46\%) were boys. The average age of the children was five years, two months, and the maximum six years, one month. Participants of the study were selected using simple random sampling methods. The participants were selected from six independent kindergartens. The sampling method was applied by drawing lots among the names of between independent preschools in the city center of Usak, affiliated to the Usak National Education Directorate. Selected five preschools have accepted to participate in the study. During the formation of the sample study group, it was taken into consideration that all children showed normal development (according to the mother and teacher views).

\section{Measurement Tools}

The two instruments used for data collection are described in turn below. Data were collected by the "The Parents' Expectations from Preschool Institutions Scale", and "Personal Information Form".

\section{Personal Information Form}

This form involves questions about children's age, gender, family's socio-economic level. The form was filled by parents.

The Parents' Expectations from Preschool Institutions Scale: “The Parents' Expectations from Preschool Institutions Questionnaire" developed by Simsek and Ivrendi (2014) was administrated in this research to determine parents' expectations from preschool education institutions. The questionnaire is a five-point Likert type and consists of four sub-scales as teacher, education-family, school policy and information, and a total of 20 items. The items are rated Strongly Disagree (1), Disagree (2), Neutral (3), Agree (4) and Strongly Agree (5). The participation levels related to questionnaire items are as follows: 4.20--5.00 Very High Expectation, 3.40--4.19 High Expectation, 2.60--3.39 Moderate Expectation, 1.80--2.59 Low Expectation, and 1.00--1, 79 Very Low level of expectation. While the Cronbach Alpha coefficient of the questionnaire was found to be .74 , the Cronbach Alpha coefficients of the sub-scales were $\alpha=.84$ for teacher, $\alpha=.75$ for family, $\alpha=.70$ for school policy and $\alpha=.66$ for information, respectively. In this investigation, whereas the Cronbach Alpha coefficient of the questionnaire determined to be $\alpha=.84$, the Cronbach Alpha coefficients of the sub-scales 
were as follows: $\alpha=.72$ for teacher, $\alpha=.61$ for education-family, $\alpha=.59$ for school policy and $\alpha=$ .50 for information.

\section{Procedure}

The data required for the study were obtained from the children's parents. First of all, permission was received from Usak Provincial Directorate for National Education for this research. Later on, it was contacted with kindergarten administrators, and teachers and administrators were provided with information about this study. Planning was made with voluntary schools to reach parents and it was decided to benefit from parents' meetings held under family involvement activities. At the beginning of these meetings, the families were given information about the scope, objective, and measurement instruments of the study, the voluntary nature, and confidentiality principles were mentioned. It was explained that their identities within the data to be obtained in this study would be kept confidential and would only be used for this scientific study. In order to provide strict confidence, participants were asked not to write their names on the questionnaires. And also, there was no identity information question related to mothers or children in data collection tools. Voluntary parents were included in the study. 350 questionnaires were filled out by parents. After examining data, 24 questionnaires filled out were excluded due to missing information, and 326 data sets were used in the analysis. It is recommended that measurement tool return rate should be above $70-80 \%$ for a proper interpretation (Buyukozturk et al., 2011). It is seen that this rate was met in this study.

The data collection tools were reviewed, classified, ranked after administration, and data entry was performed by being coded in accordance with entry format and analyzed by utilizing statistical package program. Normality, homogeneity, and independence were primarily examined in the analysis of data (Green \& Salkind, 2007). The normality of data was checked to facilitate taking decisions on statistical tests. As the sample size was larger than 50, Kolmogorov-Smirnov test recommended by Buyukozturk(2015) was administrated.

Descriptive statistics were used to describe the expectations of parents from preschool education institutions. Next, while independent samples t-test was conducted for comparisons of two groups, one-way analysis of variance (ANOVA) was administrated for comparisons among three or more groups.

\section{Results}

Table 1. Statistical information on the items of the parents' expectations from preschool institutions questionnaire

\begin{tabular}{|c|c|c|c|}
\hline Items & $\mathbf{X}$ & Ss & ExpectationLevel \\
\hline Factor 1: Teacher & 1.87 & 0.50 & Low Level \\
\hline $\begin{array}{l}\text { 1. Out-of-school activities should be organized at school } \\
\text { to strengthen communication between teachers and } \\
\text { families. }\end{array}$ & 1.97 & 0.81 & Low Level \\
\hline $\begin{array}{l}\text { 2. The priority of teacher should be to allow my child to } \\
\text { gain his/her independence. }\end{array}$ & 1.78 & 0.73 & Very Low Level \\
\hline 3. Teacher of my child should be a university graduate. & 1.69 & 0.83 & Very Low Level \\
\hline $\begin{array}{l}\text { 4. There should be an assistant teacher in my child's } \\
\text { classroom. }\end{array}$ & 1.84 & 0.88 & Low Level \\
\hline $\begin{array}{l}\text { 5. Physical characteristics (dressing, appearance) of a } \\
\text { teacher is important for me. }\end{array}$ & 2.44 & 1.24 & Low Level \\
\hline 6. My child should be provided with the ability to solve & 1.50 & 0.63 & Very Low Level \\
\hline
\end{tabular}




\begin{tabular}{|c|c|c|c|}
\hline $\begin{array}{l}\text { his/her daily problems at school. } \\
\text { 7. I should be able to watch my child whenever I want. } \\
\text { 8. Teacher of my child should talk face to face with me in } \\
\text { every term related to the development of my child. }\end{array}$ & 2.21 & $\begin{array}{l}1.07 \\
0.60\end{array}$ & $\begin{array}{l}\text { Low Level } \\
\text { Very Low Level }\end{array}$ \\
\hline Factor 2: Education-Family & 2.01 & 0.59 & Low Level \\
\hline $\begin{array}{l}\text { 10. If I make sure that my child is cared well, I consider } \\
\text { the school is adequate. }\end{array}$ & 1.91 & 0.91 & LowLevel \\
\hline $\begin{array}{l}\text { 11. I should know the families of my child's classmates. } \\
\text { 12. School should regularly hold social activities to } \\
\text { support communication among families. }\end{array}$ & $\begin{array}{l}2.18 \\
2.12\end{array}$ & $\begin{array}{l}0.92 \\
0.94\end{array}$ & $\begin{array}{l}\text { Low Level } \\
\text { Low Level }\end{array}$ \\
\hline $\begin{array}{l}\text { 13. At school, the development of my child's in counting, } \\
\text { color recognition and similar skills should be paid more } \\
\text { attention than his/her skills of making friends, } \\
\text { cooperation, etc. } \\
\text { 14. Teacher should give me a regular report on the } \\
\text { development (physical, cognitive, emotional, and social) } \\
\text { of my child in every term. }\end{array}$ & 2.06 & 0.74 & Very Low Level \\
\hline Factor 3: School Policy & 1.80 & 0.56 & Low Level \\
\hline $\begin{array}{l}\text { 9. My child should be with children of the same age in } \\
\text { his/her class. }\end{array}$ & 1.69 & 0.82 & Very Low Level \\
\hline $\begin{array}{l}\text { 15. His/her classroom should be separate from primary } \\
\text { school building. }\end{array}$ & 1.91 & 0.97 & Low Level \\
\hline $\begin{array}{l}\text { 16. School should encourage the involvement of both } \\
\text { parents in education. }\end{array}$ & 1.88 & 0.79 & Low Level \\
\hline $\begin{array}{l}\text { 17. There should be a healthcare personnel } \\
\text { (doctor/nurse) at school. }\end{array}$ & 1.71 & 0.75 & Low Level \\
\hline Factor 4: Informing & 2.32 & 0.70 & Low Level \\
\hline $\begin{array}{l}\text { 18. I should be informed daily about the activities my } \\
\text { child performs. }\end{array}$ & 2.15 & 0.95 & Low Level \\
\hline $\begin{array}{l}\text { 19. Teacher of my child should send me current articles } \\
\text { about pre-school education. }\end{array}$ & 2.23 & 0.91 & Low Level \\
\hline $\begin{array}{l}\text { 20. My child should receive education with children } \\
\text { having different family characteristics (income level, } \\
\text { ethnicity, religious preference, etc.) }\end{array}$ & 2.58 & 1.11 & Low Level \\
\hline Total & 1.96 & 0.45 & Low Level \\
\hline
\end{tabular}

The arithmetic means and standard deviation values of the answers given by parents to the questionnaire were calculated to determine their expectation levels towards preschool education institutions. It is observed that the mean values related to the questionnaire were found to be at "Low level expectation" range. When expectation level mean scores related to the sub-scales were examined, it was determined that all sub-scales had "low level" expectation as follows: teacher $(\bar{X}=1.80, \mathrm{SD}=0.50)$, education-family $(\bar{X}=2.01, \mathrm{SD}=0.59)$, school policy $(\bar{X}=1.80, \mathrm{SD}=0.56)$ and informing $(\bar{X}=2.32, \mathrm{SD}=0.70)$.

Table 2. $t$-test results on the sub-scales of the parents' expectations from preschool education institutions questionnaire according to the gender of the children

\begin{tabular}{lllllllll}
\hline & Gender & $\mathbf{N}$ & $\bar{X}$ & Ss & sd & t & p \\
\hline Teacher & Girls & 176 & 14.81 & 3.85 & & & \\
& Boys & 150 & 15.20 & 4.31 & 324 & -.871 & .39 \\
\multirow{2}{*}{ Education/Family } & Girls & 176 & 10.38 & 3.16 & & & \\
& Boys & 150 & 10.33 & 3.04 & 324 & .153 & .88 \\
\hline
\end{tabular}




\begin{tabular}{cccccccc}
\hline & & & & & & & \\
\hline School policy & Girls & 176 & 7.26 & 2.23 & & & \\
& Boys & 150 & 7.13 & 2.28 & 324 & .510 & .61 \\
Informing & Girls & 176 & 6.72 & 2.16 & & & \\
& Boys & 150 & 18.37 & 2.02 & 324 & -2.217 & .02 \\
\hline$* * \mathrm{p}<.01, * \mathrm{p}<.05$ & & & & & & &
\end{tabular}

In table 2, t-test results on the sub-scales of the parents' expectations from preschool education institutions questionnaire according to the gender of the children are seen. As a result of the study, a significant difference was found in the sub-scale of informing in favor of males. No statistically significant difference was achieved between other sub-scales of the parents' expectation questionnaire and the gender of children.

Table 3. Variance Analysis results for the sub-scales of the parents' expectations from pre-school education institutions according to the variable of socio-economic level

\begin{tabular}{|c|c|c|c|c|c|c|c|c|c|c|}
\hline $\begin{array}{l}\text { Sub- } \\
\text { Scales }\end{array}$ & $\begin{array}{l}\text { Socio- } \\
\text { economic } \\
\text { Level }\end{array}$ & $\mathrm{N}$ & Mean & $\mathrm{Sd}$ & & $\begin{array}{l}\text { Sum of } \\
\text { Squares }\end{array}$ & Df & $\begin{array}{c}\text { Mean } \\
\text { Square }\end{array}$ & $F$ & $\mathrm{p}$ \\
\hline \multirow[t]{3}{*}{ Teacher } & Lower & 51 & 16.19 & 7.33 & Between & 155.494 & 2 & 77.747 & 4.796 & $.00^{*}$ \\
\hline & Middle & 249 & 14.93 & 3.95 & Groups & 5236.494 & 323 & 16.212 & & \\
\hline & High & 26 & 13.23 & 4.13 & $\begin{array}{l}\text { Within Groups } \\
\text { Total }\end{array}$ & 5391.988 & 325 & & & \\
\hline \multirow{3}{*}{$\begin{array}{l}\text { Education } \\
\text { / } \\
\text { Family }\end{array}$} & Lower & 51 & 12.19 & 3.52 & Between & 206.498 & 2 & 03.249 & 11.387 & $.00^{*}$ \\
\hline & Middle & 249 & 10.05 & 2.90 & Groups & 2928.791 & 323 & 9.067 & & \\
\hline & High & 26 & 9.69 & 2.93 & $\begin{array}{l}\text { Within Groups } \\
\text { Total }\end{array}$ & 3135.288 & 325 & & & \\
\hline \multirow{3}{*}{$\begin{array}{l}\text { School } \\
\text { policy }\end{array}$} & Lower & 51 & 7.74 & 2.74 & Between & 23.565 & 2 & 11.783 & 2.330 & .09 \\
\hline & Middle & 249 & 7.14 & 2.18 & Groups & 1633.73 & 323 & 5.056 & & \\
\hline & High & 26 & 6.65 & $1 ., 74$ & $\begin{array}{l}\text { Within Groups } \\
\text { Total }\end{array}$ & 1656.638 & 325 & & & \\
\hline \multirow[t]{3}{*}{ Informing } & Lower & 51 & 7.05 & 1.91 & Between & 1.106 & 2 & .553 & .123 & .88 \\
\hline & Middle & 249 & 6.95 & 2.12 & Groups & 1455.376 & 323 & 4.506 & & \\
\hline & High & 26 & 6.80 & 2.44 & $\begin{array}{l}\text { Within Groups } \\
\text { Total }\end{array}$ & 1456.482 & 325 & & & \\
\hline
\end{tabular}

$(p<0.05)$

One-way analysis of variance was administrated to determine whether there was a significant difference between the income levels of families and their expectations from preschool institutions. As seen in Table 3, the expectations of families from preschool institutions showed a significant difference according to their income levels. The analysis results suggested that there was a statistically significant difference among the sub-scales of teacher $(F(4.796) ; p<.05)$ and education-family ( $F(11.387) ; p<.05)$ with the income levels of families. The Post Hoc (Tukey) procedure, applied in order to determine this difference was in favor of which group, concluded that the expectations of families with low income level from preschool institutions were higher compared to the expectations of families with middle and high income levels regarding the sub-scales of teacher and education-family. In other words, the expectations of families with low income level from preschool institutions at the subscales of teacher and education-family were higher than the expectations of families with middle- and high-income levels. 


\section{Discussion and Conclusion}

The purposes of this research were to determine the expectation levels of parents whose children were enrolled in preschool education institutions and to reveal whether some personal variables (independent variables) had any effect on families' expectations from preschool education institutions.

It was detected in this study that the sub-scale of informing had the highest value related to parents' expectations from preschool education institutions. When examining the items of this sub-scale, it was found that following items had highest rates: "I should be informed daily about the activities my child performs", "Teacher of my child should send me current articles about preschool education", "My child should receive education with children having different family characteristics (income level, ethnicity, religious preference, etc.)".In this regard, it is an element that should be included in the content of a qualified preschool education program that parents are aware of what children live in school, and teachers are informed about what children live in their families. When referring to Bronfenbrenner's bioecological model (1995), it is seen that communication is essential between the environments in which children grow. It is important for preschool education institutions to communicate with families and to establish an effective cooperation for enabling parents to contribute to the education of their children (Arnas Aktas, 2017). Investigations show that while families expect from the preschool education institutions to support different development areas of their children, they also have expectations related to the fields aiming to inform them (Sevinc, 2006, Seyfullahogullari, 2012). In a related study, parents emphasized the importance of cooperation between family and school among their expectations from the preschool education institutions, and stated the importance of their being informed about teachers related to development and progress of their children and establishing a good communication among teachers and parents (Barbarin et al., 2006). In another study carried out in Australia, parents stated that they preferred the institutions making them feel valuable and providing information on various subjects, such as development of their children and curriculum while they were preferring a preschool education institution (Noble, 2007). In a study conducted by Ceylan (2019) in Turkey parents expressed their expectations from the institution where their children were enrolled as individualization of education, related institution's being an environment similar to home environment, providing more games and activities inside and outside, and informing. Simsek and Ivrendi (2014) concluded in their study administrated with 1465 parents that the expectations of parents related to informing were high. It was argued in the investigation carried out by Seyfullahogullari (2012) by administrating semi-structured interview forms to 67 families, whose children were enrolled in private schools, in order to determine their expectations from kindergartens, the families underlined informing most, which was followed by consultancy and family education.

It was seen in this study that the sub-section having second highest mean was educationfamily related to expectations of parents. When examining mean scores of the items in the sub-scale of education-family, it is observed that following items were marked most, respectively: "I should know the families of my child's classmates $(\bar{X}=2,18)$ ", "School should regularly hold social activities to support communication among families $(\bar{X}=2,12)$ ", "At school, the development my child's in counting, color recognition and similar skills should be paid more attention than his/her skills of making friends, cooperation, etc. $(\bar{X}=2,06)$ ". Parents expect teachers to establish effective communication and cooperation and to share the information related to their children with them. There are many investigations on the 
relationship between the establishment of positive relationships with parents and an increase in parent involvement with the development of children and having early school skills of children (Dearing, Kreider, Simpkins\& Weiss, 2006; Henrich \& Gadaire, 2007; Kang, Horn\& Palmer, 2017; Weiss, Caspe \& Lopez, 2006). The parents participating in school events actively were determined to be more satisfied with the services provided. Legg (2009) conducted studies with the Marshall University Summer Enrichment Program (MUSEP) to specify which variables were most closely related to parental satisfaction. This study concluded that the parent involvement was the best predictor of parent satisfaction. The item "At school, the development of my child's in counting, color recognition and similar skills should be paid more attention than his/her skills of making friends, cooperation, etc.", which was marked frequently by parents in the sub-scale of education-family has been also found in similar prior studies. The emphasis underlined by parents to prepare their children for primary school as well as cognitive development (letters, numbers) showed that their expectations were mostly towards academic dimensions of preschool education. Related prior studies showed that there was a relationship among type and quality of preschool education institutions enrolled with academic success, the children enrolled in high quality centers were more prepared for primary school and obtained better academic results (Grogan, 2012; Krieg, Curtis, Hall \& Westernberg, 2015; LoCasale-Crouch et al., 2007; Melhuish, Belsky, Leyland \& Barnes, 2008; Pianta, Barnett, Burchinal \& Thornburg, 2009). For this reason, thoughts of parents, their reasons for preferring preschool education institutions and their expectations from these institutions are key determiners in children's being prepared for primary school and their future academic successes. In the study conducted by Foot et al. (2000) on knowledge, preferences, and expectations of parents in pre-school education institution preference, parents stated that the most important motive in institution preference was to prepare children for primary school (77\%). In addition, Bassok, Magouirk, Markowitz \& Player (2018) investigated the factors playing an important role in institution preference of the parents who enrolled their children to a preschool education institution. $88 \%$ of the parents reported that supporting academic skills was "very important".

The sub-scale of teacher is ranked third related to the expectations of parents. In this subscale, the highest mean score is obtained by the item "Physical characteristics (dressing, appearance) of a teacher is important for me" $(\bar{X}=2.44)$. This item is followed by the items "I should be able to watch my child whenever I want" $(\bar{X}=2.21)$ and "Out-of-school activities should be organized at school to strengthen communication between teachers and families" $(\bar{X}=1.97)$. The conclusions of this study differ from the conclusions of some studies in the literature. In this regard, the conclusions of this study urge that the characteristics of teachers are an important subject considered by parents in preferring preschool education institutions for their children. However, other studies reported that professional competence and experience of teachers (Barbarin et al., 2006; Elicker, Wen, Kwon \& Sprague, 2013; Peyton, Jacobs, O'Brien \& Roy, 2001; Rose \& Elicker, 2008), their being warm and friendly (Rose \& Elicker, 2008; Fairman, Logue \& LaBrie, 2016; Bassok et al., 2018) and teacher-child relationships (Barbarin et al., 2006; McNally \& Slutsky, 2018) were mostly paid attention by parents. The fact that the parents have marked the item related to the physical characteristics most may originate from their thought on teachers are role models for children.

On the other hand, the parents stated their expectations related to school policy in the last rank. In this sub-scale, the following items had the highest mean scores, respectively: "Classroom should be separate from primary school building $(\bar{X}=1.91)$ ", "School should encourage the involvement of both parents in education $(\bar{X}=1.88)$ ", "There should be a 
health care personnel (doctor/nurse) at school ( $\bar{X}=1.71)$ ". What is significant in these results is that parents are aware of the importance of separating the classes in pre-school education institutions from the primary school building. It is of importance to plan an efficient physical environment to provide a qualified education. It is significant that children receive education in a proper environment maximizing their curiosity, discover and learning wishes while feeling the warmth and safety of their homes (Fielding, 2012). Although a separate area has been attempted to be established in the kindergartens affiliated to primary education as a preschool education institution in Turkey, various problems are seen in the classes at the building of primary school buildings. An important issue to consider among these problems is the use of kindergartens affiliated to primary education. Research on this subject revealed that children remained in their classrooms, there was no proper environment for outdoor physical exercises and there were dangers in schoolyard due to being used by students from all grades (Ata, 2016). It should be reserved a separate garden area for kindergartens affiliated to primary schools as much as it is possible, if this is not possible, schoolyards should be used alternately with the students at upper grades. In addition, another expectation of parents from preschool education institutions in the sub-scale of school policy was encouragement of both parents to involve in school activities. In recent years, it is discussed more that fathers should involve in the school lives of their children. When comparing parents related to time they spend with their children, it is certain that mothers spend more time with their children compared to fathers (Wilson\& Prior, 2011). However, increasing participation of women in working life and revealing the contribution of fathers to the development of children are considered challenging factors for fathers to take an active role in child education. In addition to these, teachers and preschool education institutions should organize some studies to enable an efficient involvement of fathers (Palm\& Fagan, 2008; McWayne, Downer, Compos\& Harris, 2013). Prior research showed that parents paid attention to security and health services in the preference of preschool education institutions (Foot, Howe, Cheyne, Terras \& Rattray, 2000; Yaman Polat \& Sackes, 2017). It was also seen in some studies that the issues, such as security and health were considered more important than education (Yesil Dagli, 2012).

It was found out in this study that parents' expectations from preschool education institutions differed according to the gender of children and this difference was in favor of male children in the sub-scale of informing. The variables about children (age, gender, number of siblings, sibling rank) were not discussed much in the studies on the relationship between parents' expectations from preschool education institutions and their preferences. There are few studies discussing the relationship among gender and age of children with the views of parents on preschool education institutions (Rose \& Elicker, 2008; Natsiopoulou \& Vitoulis, 2015; Yaman Polat \& Sackes, 2017). Ahmetoglu and Acar (2017) determined that the parents of male children established more communication with teachers compared to the parents of female children. It is considered that the reason for this is originating from the fact that male children are more active or female children are more talkative.

Another conclusion of this study is that the income levels of parents had a statistically significant difference on the parent's expectations from preschool education institutions. The results suggest that the parent's expectations from preschool education institutions were significant according to income level in the sub-scales of teacher and education-family. The data analysis concluded that the expectations of parents with low income were higher from the sub-scales of teacher and education-family than the expectations of parents with middle and high-income levels. This result should be interpreted by considering the fact that the parents with higher income levels have the opportunity to benefit from various courses and 
activities for their children in addition to the education provided in preschool education institutions. This result is in parallel with the results of studies arguing that educational background and level income are effective in parents' involvement in their children's education (Leslie, Ettenson \& Cumsille, 2000; Smits \& Hosgor, 2006). Yesilyurt (2011) reported that parents' expectations from preschool education institutions differed significantly according to level income in the sub-scale of "education-family". The expectations of the parents with low income from the sub-scale of education-family were higher than the expectations of the parents with high income. There are studies showing that contextual factors such as SEL level affect parents' expectations about preschool education institutions and their reasons for preference (Barbarin et al., 2006; Grogan, 2012).

\section{Discussion}

When evaluating the results of this research in general, it is seen that the expectations of parents related to school-teacher-family communication are high. The families mostly consider that sufficient family involvement activities are not carried out at schools. In the parents' expectations from preschool institutions questionnaire, parents preferred the following items in the related sub-scales high rates: "I should be informed daily about the activities my child performs" (the sub-scale of informing), "I should know the families of my child's classmates" and "School should regularly hold social activities to support communication among families" (the sub-scale of education-family), "Out-of-school activities should be organized at school to strengthen communication between teachers and families" (the sub-scale of teacher), "School should encourage the involvement of both parents in education" (the sub-scale of school policy). The results obtained in this study confirm that parents do not involve in education of their children sufficiently. Investigations show that the positive involvement of parents in the early childhood period help children's cognitive enhancement, being prepared for school and their successes (Kreider, 2002). Because the learning and development of children do not only depend on the child but also is shaped by cultural and social characteristics of societies and families (Mc-Farland-Piazza \& Saunders, 2012). In addition, Bronfenbrenner's theory emphasizes the cooperation need between schools and parents. These results suggest that the involvement of parents in preschool education should be improved.

\section{Suggestions}

Although it is not possible to generalize the results of this research, it can be urged that they are in accordance with the views of many parents in this respect as well as related literature. The results of this study are guiding for the individuals responsible for legal arrangement, operation and education of institutions. It is suggested to carry out activities and organizations to enable the direct involvement of parents in the educational processes of their children in line with the results obtained in this study. Preschool teachers' awareness related to family involvement studies is an opportunity to carry out family involvement studies effectively. In this regard, it is considered important for teachers to participate in necessary training and courses during their education on cooperation and communication with families and increasing family involvement.

It was determined in this study that parents' expectations were at low level at all sub-scales of the parents' expectations from preschool institutions questionnaire. Conducting qualitative and/or longitudinal studies regarding the reasons for this low expectation level will be useful in planning education. 
Parents should be informed about the fact that the purpose of preschool education is not only provide academic support, but supporting the social-emotional development of children is of importance in both preparing children for primary schools and their relationships with their teachers and peers.

This study is a significant first step in the determination of processes associated with the expectations of parents from preschool education institutions. It will be useful to specify the expectations of teachers and educational institution administrators from parents based on this perspective. In addition, comparisons may be made by planning intercultural studies.

It is of paramount importance to carry out such investigations after the pandemic process. Thus, it will be determined whether the expectations of families related to social distance, hygiene, and similar subjects, which are emphasized more following the pandemic period, have changed or not.

\section{Compliance with Ethical Standards}

Conflict of Interest The author, Sibel Yoleri personally has not received any funding for this project. Therefore, the author declares that they have no conflict of interest to disclose.

Ethical Approval All procedures performed in studies involving human participants were in accordance with the ethical standards of the institutional and/or national research committee and with the 1964 Helsinki declaration and its later amendments or comparable ethical standards.

Informed Consent form was obtained from the parents of children in the study.

\section{References}

Ahmetoglu, E.\& Acar, I.H. (2017). Parents' satisfaction with their children's educational experiences in early childhood period. Turkish Studies, 12(6), 1-14.

Arnas Aktas, Y. (Eds.) (2017). Aile egitimi ve okul oncesinde aile katilimi. Ankara: Vize Yayincilik.

Ata, S. (2016). Okul oncesi ogretmenlerinin dis mekanda uygulamalari ve cocuklarin dis mekanda oyun oynamalarina ilisin goruslerinin incelenmesi (Unpublished Master Thesis). Hacettepe Universitesi, Ankara.

Barbarin, O.A., McCandies, T., Early, D., Clifford, R.M., Bryant, D., Burchinal, M., Howes, C.\&Pianta, R. (2006). Quality of prekindergarten: What families are looking for in public sponsored programs. Early Education and Development, 17(4), 619-642.

Bassok, D., Magouirk, P., Markowitz, A. J.\& Player, D. (2018). Are there differences in parents' preferences and search processes across preschool types? Evidence from Louisiana. Early Childhood Research Quarterly, 44, 43-54. doi:10.1016/j.ecresq.2018.01.006

Berk, L.E. (2005). Infants and children: Prenatal through middle childhood (5th ed.). Toronto: Allyn \& Bacon.

Bespinar, F. U.\& Aybars, A. I. (2013). Erken yaslarda cocuk refahi ve kadin istihdami politika belgesi. Turkiye: T.C. Calisma ve Sosyal Guvenlik Bakanligi\& UNICEF.

Bronfenbrenner, U. (1995). Developmental ecology through space and time: A future perspective. In P. Moen, G. H. Elder, Jr., K. Lusher \& U. Bronfenbrenner (Eds.), 
Examining lives in context: Perspectives on the ecology of human development (pp. 619-647). Washington, DC: American Psychological Association.

Bronfenbrenner, U., \& Morris, P.A. (2006). The Bioecological Model of Human Development. In R. M. Lerner \& W. Damon (Eds.), Handbook of child psychology: Theoretical models of human development (p. 793-828). John Wiley \& Sons Inc.

Buyukozturk, S. (2015). Sosyal bilimler icin veri analizi. Ankara: Pegem Yayinlari.

Buyukozturk, S., KilicCakmak, E., Akgun, O.E., Karadeniz, S.\& Demirel, F. (2011). Bilimsel arastirma yontemleri. Ankara: Pegem Yayinlari.

Ceglowski, D.\& Bacigalupa, C. (2002). Four Perspectives on Child Care Quality. Early Childhood Education Journal, 30 (2), 87-92.

Ceylan, R. (2019). Ebeveynlerin okul oncesi kurumu hakkindaki gorusleri: tercih sebepleri, beklentileri ve memnuniyetleri. Elektronik Sosyal Bilimler Dergisi, 18(70), 497-517.

Checchi, D. (2006). The economics of education. Cambridge: Cambridge University Press.

Christenson, S.L., \& Sheridan, S.M. (2001). Schools and families: Creating essential tools for learning. New York, NY: Guilford.

Council of the European Union Commission (2011). Council's conclusions on early childhood education and care: providing all our children with the best start for the world of tomorrow. Retrieved from: http://eur-lexeuropa.eu/legalcontent/EN/TXT/PDF/?uri=OJ:C:2011:175:FULL\&from=EN.

da Silva, L.\& Wise, S. (2006). Parent perspectives on childcare service quality among a culturally diverse sample. Australian Journal of Early Childhood, 31(3), 6-14.

Daphina, L.M., \& Begi, N. (2020). Influence of demographic factors and type of school on parents satisfaction with the quality of pre-primary education in Dar Es Salaam, Tanzania. European Journal of Education Studies, 7(5),147-162.

Dearing, E., Kreider, H., Simpkins, S., \& Weiss, H.B. (2006). Family involvement in school and low-income children's literacy: Longitudinal associations between and within families. Journal of Educational Psychology, 98(4):653-664.

DeLoatche, K.J., Bradley-Klug, K. L., Ogg, J., Kromrey, J. D. \& Sundman-Wheat, A.N. (2014). Increasing parent involvement among head start families: a randomized control group study. Early Childhood Education Journal, 43(4), 271-279. doi:10.1007/s10643-014-0660-7

Elicker, J., Wen, X., Kwon, A.A. \& Sprague, J.B. (2013). Early head start relationships: Association with program outcomes. Early Education and Development, 24(4), 491-516. doi:10.1080/10409289.2012.695519.

Fairman, J.C., Logue, M. E. \& LaBrie, S. (2016) Factors influencing parents' decision to use public pre-K programs in Maine: Results of a parent survey. A report of the Maine Education Policy Research Institute (MEPRI). Orono, ME: University of Maine.

Fantuzzo, J., Perry, M. A.\& Childs, S. (2006). Parent satisfaction with educational experiences scale: a multivariate examination of parent satisfaction with early childhood education programs. Early Childhood Research Quarterly, 21(2), 142-152.

Fielding, R. (2012). Leaner, more effective schools. School Business Affairs, 78(10), 12-16.

Foot, H., Howe, C., Cheyne, B., Terras, M. \& Rattray, C. (2000). Pre-school education: Parents' preference, knowledge and expectations. International Journal of Early Years Education, 8(3), 189-204. http://dx.doi.org/10.1080/09669760050156730

Forry, N. D., Simkin, S., Wheeler, E. J.\& Bock, A. (2013). You know how it makes you feel "lowincome parent's childcare priorities and definitions of ideal high-quality childcare. Journal of Children and Poverty, 19(2), 107-126. doi:10.1080/10796126.203843508

Friedman, B.A., Bobrowski, P. E. \& Markow, D. (2007). Predictors of parents' satisfaction with their children's school. Journal of Educational Administration, 45(3), 278-288. 
Friedman, B., Bobrowski, P. \& Geraci, J., (2006). Parents' school satisfaction: Ethnic similarities and differences. Journal of Educational Administration, 44(5), 471-486.

Glenn-Applegate, K., Pentimonti, J.\& Justice, L. (2011). Parents' selection factors when choosing preschool programs for their children with disabilities. Child \& Youth Care Forum, 40(3), 211-231. doi:10.1007/s10566-010-9134.

Grogan, K.E. (2012) Parents' choice of pre-kindergarten: The interaction of parent, child and contextual factors. Early Child Development and Care, 182(10), 12651287, DOI: $10.1080 / 03004430.2011 .608127$

Grolnick, W.S., Friendly, R. \& Bellas, V. (2009). Parenting and children's motivation at school. In K.R. Wentzel\& A. Wigfield (eds.), Handbook of motivation at school (pp. 279-300). Mahwah, NJ: Erlbaum.

Gursimsek, I. (2003). Okul oncesi egitime aile katilimi ve psikosoyal gelisim. Kuram ve Uygulamada Egitim Bilimleri, 3(1), 125-144.

Henrich, C. C.\& Gadaire, D.M. (2007). Head Start and parent involvement. Infancy \& Young Children, 21(1), 41-54.

https://www.naeyc.org/our-work/families/10-naeyc-program-standards

Huston, A.C., Chang, Y. E. \& Gennetian, L. (2002). Family and individual predictors of child care use by low-income families in different policy contexts. Early Childhood Research Quarterly, 17, 441-469.

Jacobson, A.L. \& Engelbrecht, J. (2000). Parenting Education Needs and Preferences of Parents of Young Children. Early Childhood Education Journal, 28(2), 104-116.

Kang, J., Horn, E. M. \& Palmer, S. (2017). Influences of family involvement in kindergarten transition activities on children's early school adjustment. Early Childhood Education Journal, 45(6), 789-800.

Karasar, N. (2012). Bilimsel arastirma yontemleri. Ankara: Nobel Yayin Dagitim.

Krieg, S., Curtis, D. \& Hall, L.\& Westerberg, L. (2015). Access, quality and equity in early childhood education and care: A South Australian study. Australian Journal of Education, 59(2), 119-132. doi:10. 1177/0004944115588789

Lasser, J. \& Fite, K. (2011). Universal preschool's promise: Success in early childhood and beyond. Early Childhood Education Journal, 39, 169-173.

Legg, K.D. (2009). Parent satisfaction with Marshall University's summer enrichment program. Years four and five. Electronic thesis retrieved on March 15th, 2020 from http://marshall.edu.etd.masters/legg-kimberly-2009- eds.pdf.

Leslie, L. A., Ettenson, R.\& Cumsille, P. (2000). Selecting a child care center: What really matters to parents? Child and Youth Care Forum, 29, 299-322.

Liang, X., Fuller, B.\& Singer, J. (2000). Ethnic differences in child care selection: The influence of family structure, parental practices, and home language. Early Childhood Research Quarterly,15(3), 357-384.

LoCasale-Crouch, J., Konold, T., Pianta, R., Howes, C., Burchinal, M., Bryant, D. (2007). Observed classroom quality profiles in state-funded pre-kindergarten programs and associations with teacher, program, and classroom characteristics. Early Childhood Research Quarterly, 22(1), 3-17.

Mc-Farland-Piazza, L. \& Saunders, R. (2012). Hands on parent support in positive guidance: Early childhood professionals as mentors. Australasian Journal of Early Childhood, 37(1) 65-73.

McNally, S. \& Slutsky, R.(2018)Teacher-child relationships make all the difference: constructing quality interactions in early childhood settings. Early Child Development and Care, 188(5), 508-523, DOI: 10.1080/03004430.2017.1417854 
McWayne, C., Downer, J. T., Campos, R. \& Harris, R.D. (2013). Father involvement during early childhood and its association with children's early learning: A meta-analysis. Early Education and Development, 24(6), 898-922,

McWayne, C., Hampton, V., Fantuzzo, J., Cohen, H.L. \& Sekino, Y. (2004). A multivariate examination of parent involvement and the social and academic competencies of urban kindergarten children. Psychology in the Schools, 41(3), 363-377. doi:10.1002/pits.10163

Melhuish, E., Belsky, J., Leyland, A.\& Barnes, J. (2008). Effects of fully established Sure Start Local Programmes on 3-year-old children and their families living in England: A quasiexperimental observational study. The Lancet, 372(9650), 16411647. https://doi.org/10.1016/S0140-6736(08)61687-6

Meyers, M. K., Lucy, P.\& Jordan, L.P. (2009). Choice and accommodation in parental child caredecisions. Community Development,37(2), 53-70.

National Association for the Education of Young Children (2008). Overview of NAEYC. Early Childhood Program Standards. Retrieved: 08.07. 2020.

Natsiopoulou, T. \& Vitoulis, M. (2015). Criteria of parents for choosing preschool centers during the period of economic crisis in Greece. International Journal of Caring Sciences, 8(3), 698-708.

Navarro-Cruz, G. \& Luschei, T. (2020). Quality preschool as defined by Latina mothers: A qualitative study using a funds of knowledge framework, Journal of Research in Childhood Education, 34(1), 6-27, DOI: 10.1080/02568543.2019.1692102

Noble, K. (2007). Complexities and compromises. Australian Journal of Early Childhood, 32(1), 24-29.

Palm, G. \& Fagan, J. (2008). Father involvement in early childhood programs: Review of the literature. Early Child Development and Care, 178(7-8), 745-759,

Penn, H. (2009). European Commission/NESSE (Network of experts in social sciences of education training). Early childhood education and care: Key lessons from research for policy makers. Brussels: Retrieved from: 08.07. 2020. http://www.http://www.nesse.fr/nesse/activities/reports/ecec-report-pdf.

Peyton, V., Jacobs, A. C., O'Brien, M. \& Roy, C. (2001). Reasons for choosing childcare: Associations with family factors, quality and satisfaction. Early Childhood Research Quarterly, 16, 191-208.

Pianta, R., Barnett, W.S., Burchinal, M. \& Thornburg, K.R. (2009). The effects of preschool education: What we know, how public policy is or is not aligned with the evidence base, and what we need to know. Psychological Science in the Public Interest, 10, 49-88.

Rolnick, A. \& Grunewald, R. (2003). Early childhood development: Economic development with a high public return. The Region, 17(4), 6-12.

Rose, K.K., \& Elicker, J. (2008). Parental decision making about child care. Journal of Family Issues, 29(9), 1161-1184.

Schulman, K. \& Barnett, S. (2005). The benefits of prekindergarten for middle income children. National Institute for Early Education Research. Available at http://nieer.org/resources/policyreports/report3.pdf.

Sevinc, M. (2006). Okul oncesi egitimi alan cocuklarin annelerinin okuldan beklentileri. Ataturk Universitesi, Kazim Karabekir Egitim Fakultesi, 13(1), 218-225.

Seyfullahogullari, A. (2012). Ailelerin anaokullarindan beklentileri uzerine bir arastirma. The Journal of Marmara Social Research, 2, 1-15.

Simsek, Z.C., \& Ivrendi, A. (2014). Ebeveynlerin okul oncesi egitim kurumlarindan beklentileri. Hacettepe Universitesi Egitim Fakultesi Dergisi, 29(2), 240-254. 
Smits, J. \& Hosgor, A.G., (2006). Effects of family background characteristics on educational participation in Turkey. International Journal of Educational Development, 26, 545-560.

Weiss, H.B, Caspe, M., \& Lopez, M. E. (2006). Family involvement makes a difference: Family involvement in early childhood education. Cambridge, MA: Harvard Family Research Project. Available at http://www.gse.harvard.edu/hfrp/content/ projects/fine/resources/research/earlychildhood.html

Wilson, K.R., \& Prior, M.R. (2011). Father involvement and child well-being. Journal of Pediatrics and Child Health, 47, 405-407.

Yaman Polat, R. \& Sackes, M. (2017). Anne-babalar okul oncesi egitim kurumu yoneticilerinden ne bekliyor? Anne-baba ve yonetici beklentilerinin karsilastirilmasi. Erken Cocukluk Calismalari Dergisi. 1(1), 94-103.

Yesil Dagli, U. (2012). Cocuklari okul oncesi egitim kurumlarina devam eden velilerin onem verdikleri kurum ozellikleri. Gaziosmanpasa Universitesi Sosyal Bilimler Arastirmalari Dergisi, 7(2), 266-286.

Yesilyurt, Z.C. (2011). Turkiye'de Cocuklari Okul Oncesi Egitim Kurumlarina Devam Eden Ebeveynlerin Okul Oncesi Egitim Kurumlarindan Beklentileri ve Okul Oncesi Egitim Kurumlarinin Bu Beklentileri Karsilama Durumlari. Master's Thesis. Pamukkale Universitesi Sosyal Bilimler Enstitusu.

\section{Biographical notes:}

Dr. Sibel Yoleri is an Assoc. Professor at the Department of Preschool Education, Izmir Demokrasi University, Turkey. Her areas of research interests include temperament characteristics in early childhood, problem behaviors, and school adjustment in early childhood. Some of her articles have been published in journals: South African Journal of Education, Education \& Science Journal, Education 3-13 (International Journal of Primary, Elementary and Early Years Education), International Electronic Journal of Environmental Education, and Cypriot Journal of Educational Sciences (CJES). 